\title{
Analysis and Fabrication of an Active Cooling System for Reducing Photovoltaic Module Temperature
}

\author{
Abdul Qayoom Jakhrani \\ Department of Energy and Environment \\ Engineering, \\ Quaid-e-Awam University of \\ Engineering, Science and Technology, \\ Nawabshah, Pakistan \\ aqunimas@hotmail.com
}

\author{
Abdul Rehman Jatoi \\ Department of Energy and Environment \\ Engineering, \\ Quaid-e-Awam University of \\ Engineering, Science and Technology, \\ Nawabshah, Pakistan \\ arjatoi@quest.edu.pk
}

\author{
Sadam Hussain Jakhrani \\ Department of Civil Engineering \\ COMSATS Institute of Information \\ Technology, \\ Sahiwal, Punjab, Pakistan \\ sadamhussain@ciitsahiwal.edu.pk
}

\begin{abstract}
The purpose of this study is to fabricate and analyze an active cooling system for reducing photovoltaic (PV) module temperature and increasing its efficiency. An active cooling system was devised to cool the PV module. Two modules of same specifications were used for this study. One module was cooled, and other was left un-cooled for performance comparison. Solar radiations, wind speed, ambient temperature and temperatures at different points of the fabricated system were measured. The modules were mounted on a frame facing true south at the inclination of the latitude of the location. The measurements were taken during daytime with one hour intervals for two weeks. The temperatures at various points on cooled and un-cooled photovoltaic modules were noted using two different flow rates with $1 \mathrm{lit} / \mathrm{min}$ and $2 \mathrm{lit} / \mathrm{min}$. It was discovered that the efficiency of PV module was enhanced from $6 \%$ to $7 \%$ during study period. The flow rate of $1 \mathrm{lit} / \mathrm{min}$ was found more feasible for heat extraction as compared to the flow rate of $2 \mathrm{lit} / \mathrm{min}$. The wind speed was found to be more helpful for heat extraction from the modules as compared to other climatic parameters.
\end{abstract}

Keywords-active cooling system; photovoltaic module; module temperature

\section{INTRODUCTION}

Solar energy is an environmental friendly source of electric power generation and at the same time cannot be affected by escalation of fuel price. A solar photovoltaic (PV) system converts sunlight directly into electricity. It comprises of cells, modules, panels, arrays and other auxiliary components, such as storage batteries, inverter/convertor and charge controller. Solar cells are fundamental component of PV systems. A solar cell is a tiny semi-conductor device which has a light sensitive $\mathrm{p}-\mathrm{n}$ junction. When solar radiation hit the $\mathrm{p}-\mathrm{n}$ junction, dc electric motive force is generated with p-terminal as positive and n-terminal as negative. A single solar cell has a rated voltage of about 0.45 Volts dc, current of about 0.75 Amperes $\mathrm{dc}$, and a rated power of 0.33 Watts [1]. When the cells are arranged in series or parallel or combination of both constitute a solar photovoltaic module or panel. Photovoltaic modules usually have a glass pane on the sun-facing side, permitting light to pass through its cover and shielding the semiconductor wafers from deterioration. Solar cells for remote applications are normally made from silicon as single-crystalline, polycrystalline or amorphous solids, however, thermophotovoltaics are also in research and development stage and may be commercialized soon. The monocrystalline cells are made up of single-crystalline silicon that has a distinct continuous crystal lattice structure with almost no defect of impurities. Although, it is more expensive to manufacture, it has higher efficiency of around $15 \%$ compared to its counterparts. Polycrystalline cells are produced using several particles of single-crystalline silicon, and they have more disarranged atomic structure, leading to lower efficiency of about $12 \%$. These are less expensive and more resistant to degradation due to irradiation. In amorphous or thin film silicon cells, the silicon particles are spread over the transparent surface. An amorphous silicon cell is composed of silicon atoms in a thin identical layer and absorbs light more effectively than crystalline silicon. These cells have lower efficiency of around 6\%. For thin film cells, a very thin layer of silicon is required with a mixture of another material like glass for holding the silicon. At present, the efficiency of commercial thin film modules is around 5-7\% [1-5]. Moreover thermophotovoltaics are photovoltaic devices that use infrared radiations. Besides the above type of cells, numerous other favorable materials, such as cadmium telluride and copper indium diselenide are used currently for photovoltaic applications [3].

\section{A. Working Principle of Photovoltaic Cell}

Photovoltaic cell is a light sensitive, two terminal semi conducting n-p junctions, made up of semi-conducting material such as silicon. A solar cell has two layers, one is n-type and other is p-type and two subsequent electrodes, negative and positive. N-type material is achieved by the doping silicon crystal with n-type impurity, whereas, p-type material by doping silicon crystal with p-type impurity. P-type layer is 
thick and the n-type layer is thin and ostensible. When the sun light hit the n-type thin layer, some of the waves of light energy enter up to p-type layers. The electrons are freed from n-type material and holes are created in p-type material. The electrons are negatively charged and holes are positively charged. When external electric circuit is finalized by joining electrodes to the load, the electrons flow in the closed external circuit from ntype terminal (-ve) to p-type terminal (+ve). The direction of current, by conversion, is from (+ve) terminal p-type to (-ve) terminal n-type in the external circuit, thus, electron hole pairs are generated within $n-p$ junction regularly during the incidence of the sun-light [2-4]. Hence, energy from solar rays is captured by photovoltaic cells and is converted directly to electrical energy [4].

\section{B. Power Output of Photovoltaic Modules}

Power output is an important factor to be considered for selection of photovoltaic (PV) modules. The performance of PV modules is a function of the amount of available and received solar radiation, ambient temperature and air mass. The power output of PV modules is almost proportional to the sun's intensity. At a given solar intensity, the output current and operating voltage of PV module can be determined with the help of load characteristics. If that load is a battery, then its internal resistance will govern the module's operating voltage. The photovoltaic energy generation and the corresponding efficiency of PV modules can be defined as the ratio of the output energy produced by the PV modules to the incident solar radiation. The principal advantages of PV systems includes low maintenance cost, zero operation cost, conservation of energy, protection of environment, no noise production and more reliable as compared to other power generating sources. It is reported that a photovoltaic system installed with a maximum power output of $1 \mathrm{~kW}$ for an entire year period, can save around $1300 \mathrm{kWh}$ of electrical energy and $800 \mathrm{~kg}$ of $\mathrm{CO}_{2}$ emissions [4-5].

\section{Factors Affecting Performance of Photovoltaic Modules}

The performance of PV modules can be evaluated from the performance of its components which can be affected by climatic factors and associated losses. The rated power of PV modules are homogenized under standard test conditions, STC, with the solar irradiance of $1000 \mathrm{~W} / \mathrm{m}^{2}$, air mass of 1.5 and temperature of $25^{\circ} \mathrm{C}$. Nevertheless, the outdoor environment is varied due to random nature of climatic conditions [4]. The solar energy reaching earth's surface is equivalent to 1367 $\mathrm{W} / \mathrm{m}^{2}$, which is almost constant. However, many factors contribute the efficiency loss of PV modules except the reflection of clouds and earth's own surface as given in Table I [5-6].

\section{Influence of Temperature on Photovoltaic Modules}

The operating temperature is one of the most important parameters in the conversion process of photovoltaic cells. As the cell temperature increases there is reduction of its voltage output. Since the output current is quite stable, the drop of voltage leads to a decrease of electrical conversion efficiency. Photovoltaic cells perform better in cold rather than in hot climate. For each degree rise in temperature above $25^{\circ} \mathrm{C}$, the
PV module output decays nearly $0.25 \%$ for amorphous and around $0.4-0.5 \%$ for crystalline (mono or poly) cells. It shows that the PV modules will produce $25 \%$ less power as compared to the rated power of $25^{\circ} \mathrm{C}$. Thus, a $100 \mathrm{~W}$ module will produce only $75 \mathrm{~W}$ in hottest months when temperatures reach up to $45^{\circ} \mathrm{C}$ or more. Photovoltaic modules are made by the assemblage of solar cells, which operate as a quantum device exchanging photons for electrons. The output of solar cells is affected by various external (climatic) and internal (material properties) factors. The open circuit voltage, $\mathrm{V}_{\mathrm{oc}}$, and short circuit current, $\mathrm{I}_{\mathrm{sc}}$, depends upon the solar irradiance and the temperature as shown in 1 and 2.

$$
\begin{aligned}
& V_{o c}=\frac{K T}{q} \ln \frac{I_{s c}}{I_{o}} \\
& I_{s c}=b H
\end{aligned}
$$

where,

$\mathrm{I}_{\mathrm{o}}$ is the saturation current,

$\mathrm{q}$ is the electronic charge

$\mathrm{K}$ is the Boltzmann constant,

$\mathrm{T}$ is the absolute temperature,

$\mathrm{H}$ is the incident solar radiation and

$\mathrm{b}$ is a constant depends on the properties of the semiconductor material [7].

Ominously, a PV module converts only 6-20\% of the incident solar radiation into electricity, the rest is converted into heat, which significantly increases the temperature of the module and reduces its efficiency. Several researches have been carried out in order to discover the effect of temperature on the efficiency of PV modules and to reduce its consequences.

TABLE I. FACTORS AFFECTING PERFORMANCE OF PV MODULE

\begin{tabular}{|c|c|}
\hline Effect & Range \\
\hline Temperature & $1-10 \%$ \\
\hline Incidence Angle & $1-5 \%$ \\
\hline Solar Spectrum & $1-3 \%$ \\
\hline Mismatch & $2 \%$ \\
\hline Soiling & $0-15 \%$ \\
\hline Snow and Shading & Location dependent \\
\hline Ageing & $5 \%$ over lifetime \\
\hline Power rating & $0-5 \%$ or more \\
\hline Diodes \& wiring & $3 \%$ \\
\hline
\end{tabular}

\section{E. Methods for Reducing Temperature of PV Module}

A decrease in the PV module temperature will lead to an increase in electrical efficiency. The efficiency which drops with the rise of temperature is approximately $0.5 \% /{ }^{\circ} \mathrm{C}$. Increase in electrical efficiency is mainly dependent on different cooling techniques, types and size of the module, geographical location/position and season of the year. The construction and maintenance of cooling systems are main issues. These expenses may outweigh the benefits of the improved electrical yield. Therefore, care must be taken at the time of selection and implementation of any cooling method. The two most famous 
PV cooling methods comprise of either passive or active techniques. Passive cooling uses natural convection/conduction to enable heat extraction, whereas, the active cooling consumes energy (pump, fan, etc).

\section{1) Passive Cooling Techniques}

Passive cooling is a natural technique for heat dissipation and modulation without utilization of energy source or power. The procedure involves transporting heat from where it is generated and dissipating it to the environment. The simple passive cooling techniques include the use of high thermal conductivity metals (aluminum and copper), or fins or other extruded surfaces to enhance heat transfer to the ambient atmosphere. The complex systems comprised of the phase change materials (PCMs) and use of heat pipes to transfer heat efficiently through a boiling-condensing process. Passive cooling techniques can be further divided into three categories: air passive cooling, water passive cooling and conductive passive cooling. Authors in [8] studied the behavior of polycrystalline PV cells in controlled conditions. For that, two PV cells were used, one with aluminum fins as a heat sink with thermal grease and other without a heat sink. Illumination was varied from 200 to $800 \mathrm{~W} / \mathrm{m}^{2}$. A relative increase in electric efficiency of $9 \%$ has been gained via usage of passive cooling with a heat sink. Authors of [9] reported that the depth of flow channel beneath PV cells has significant influence on passive cooling, for larger PV surface $\left(1.95 \mathrm{~m}^{2}\right)$. It has been shown that, for a length-to-depth ratio of 0.085 , the PV module heats up by $5-6^{\circ} \mathrm{C}$ when compared with a PV module on a regular mount. It has been noted that the temperature difference rises with the increase of insulation. In other words, passive flow channels can have the reverse effect on PV module cooling. A special type of passive conductive cooling is phase change material cooling, PCM, which is considered as a complex type of cooling. Although this can't be viewed as cooling in the strict sense, it keeps maintaining the same temperature. It can still be counted as a passive technique mainly because of the fact that no additional work or energy is needed to take away the heat-it is dissipated mostly conductively. Author in [10] reported that the use of proper PCM material could decrease $15^{\circ} \mathrm{C}$ temperature of $\mathrm{PV}$ cell as compared to reference conditions and with the insolation of $1000 \mathrm{~W} / \mathrm{m}^{2}$. PV modules with nominal power of $65 \mathrm{~W}$ were used, with $50 \mathrm{~mm}$ of PCM material from the back, with vertical aluminum fins to enhance conduction. The power gained was more than $9.7 \%$ from a reference PV module.

Authors in [11] investigated the performance and costs for a passively cooled, single cell high concentrated PV receiver, whose concentration range is between 100 and 1000. It has been found that aluminum performs better than copper as a heat sink material. The optimized finned heat sinks made of aluminum have shown the ability to keep a $3 \mathrm{~mm} \times 3 \mathrm{~mm}$ cell temperature below $60^{\circ} \mathrm{C}$ and $80^{\circ} \mathrm{C}$ degrees under standard conditions of $1000 \mathrm{~W} / \mathrm{m}^{2}$ with material costs of $0.57 \$ / \mathrm{Wp}$ and $0.18 \$ / \mathrm{Wp}$, respectively. In [12] the operating temperature of PV modules were reduced by means of ribs at different angles. Moreover, the temperature of the PV module was also decreased using heat sinks, which accounted the reduction of $10^{\circ} \mathrm{C}$ from the base case. Thus, the maximum power produced was more than $90 \%$ of the nominal one. Authors in [13] investigated thermal and electrical performance of flat PV module with cotton wick cooling system in combination with water, $\mathrm{Al}_{2} \mathrm{O}_{3} /$ water nanofluid and $\mathrm{CuO} /$ water nanofluid. They have got module temperature reduction in between $11 \%$ and $17 \%$ as compared to the module temperature obtained without cooling.

\section{2) Active Cooling Techniques}

Active cooling systems involve the use of energy and consume power in order to cool the photovoltaic module. In this system, a coolant is used to circulate and transfer heat from one place to another. The coolant is either a gas (air) or a liquid (water or other chemical). In the case of liquid, this in turn is cooled by passing air over it. Most of the methods are based on the air or water cooling. Hence, the main consumption system is pump or fan needed for maintaining fluid circulation. In general, active cooling systems give more production of power and thermal energy, however, power is also consumed in the system itself, which must be taken into account. Authors in [14] worked on the cooling of four polycrystalline modules with the rated power of $55 \mathrm{~W}$ from back side. The surface of PV module was $0.78 \mathrm{~m}^{2}$. Special flow channel was made and CFD analysis was used to optimize its shape. Total efficiency gain was around $1 \%$, depending of the solar irradiation. Optimal air flow beneath the panel was $0.055 \mathrm{~kg} / \mathrm{s}$, although no ambient temperature was given. This information is therefore reliable only for this specific case. Nevertheless, it can be valuable when trying to evaluate the amount of air needed to cool down the standard PV module. As for water cooling, two distinct techniques can be applied, for example, front side and back side cooling. Authors in [15] created a thin water film at front side of a monocrystalline PV module and gained total efficiency increase of about $1 \%$. The total area of module was $0.44 \mathrm{~m}^{2}$ and maximum water flow was kept around $1 \mathrm{lit} / \mathrm{min}$. The pump used for circulating water was $0.25 \mathrm{hp}$. A decrease in temperature of $20^{\circ} \mathrm{C}$ was achieved. They did not mention the amount of heat taken off by evaporation, which should be taken into account when cooling is done from the front side.

Authors in [16] worked on the active cooling technique for concentrated monocrystalline PV cell of $0.152 \mathrm{~m}^{2}$. The concentration was at the intensity of 8.5 suns. The cooling technique used was back side cooling via two aluminum pipes on aluminum mounting. Peak efficiency gain was $0.8 \%$ for mass flow of $0.035 \mathrm{~kg} / \mathrm{s}$ of water. Peak PV temperature was around $60^{\circ} \mathrm{C}$. Authors in [17] performed an experimental work on the cooling of a monocrystalline PV module with an area of $1.24 \mathrm{~m}^{2}$ from back side, via closed casing through which a flow of water was established. In experiment, a jet entrainment of water was considered. Water pump demanded $0.5 \mathrm{hp}$ at the maximum mass flow of $0.06 \mathrm{~kg} / \mathrm{s}$. The maximum efficiency obtained was $2.8 \%$ as compared with non-cooled module with a decrease of $10^{\circ} \mathrm{C}$ in PV module temperature. Considering the size of the module, the rise in efficiency was significant and a substantial change in temperature was achieved. Authors in [18] worked on active cooling of PV module by passing the water on the surface of the module. They used monocrystalline PV panel of $1.25 \mathrm{~m}^{2}$ surfaces, and cooled it with a water flow on the front side of the panel. The pump demand was around 1 $\mathrm{hp}$. Flow of the water was fixed at $0.48 \mathrm{~kg} / \mathrm{s}$. The cooling was made in intervals of 5 minutes, with 15 minute pauses. The 
cooling rate was found $2^{\circ} \mathrm{C} / \mathrm{min}$. The total increase in efficiency, as a result of cooling was about $1.5 \%$. It was proposed that an optimal temperature for cooling initiation should be $45^{\circ} \mathrm{C}$. The front of the panels should be cleaned, especially for dusty regions such as Sahara or Middle East. Solar energy is one of the cheap, ever-present and environmental friendly sources of energy. It can be utilized for generation of heat, and electricity either by means of thermal technologies or PV modules. However, the power out of photovoltaic modules is being affected externally by climatic factors or internally by module materials. Moreover, the performance can also be decreased by the heat buildup beneath the PV modules, which may lead to decrease electrical power output and life span of module. Therefore, cooling of PV modules not only increases the power output of PV module but also life of these generating units.

\section{MATERIALS AND METHODS}

\section{A. Materials and Instruments}

The materials used for fabrication and installation PV module cooling system were monocrystalline module, air duct, heat exchanger, thermoset, silicone gel, water tank, water pump, metal stand and structure. Two monocrystalline PV modules, each with a rated power of $10 \mathrm{~W}$ were used for this study, and their electrical characteristics are given in Table II. The materials for metal stand include metal rods, pulley, screws, bearings, frame etc. Duct fitted with silicon jell on the stand. An electrical switch button was made up of plastic used to turn $\mathrm{ON}$ and OFF the data logger and motor when they were not in use. The instruments used for the analysis were data logger, anemometer and lux meter. An Arduino UNO R3 data logger was used for data logging purpose and its specifications are shown in Table III.

TABLE II. SPECIFICATIONS OF MONOCRYSTALLINE PV MODULE

\begin{tabular}{|c|c|}
\hline Type & Solar module \\
\hline Model & JH10-18M \\
\hline Rated Maximum Power & 10 Watt \\
\hline Rated Voltage & 9 Volt \\
\hline Rated Current & 1.11 Ampere \\
\hline Opened-circuit Voltage & 10.8 Volt \\
\hline Short-circuit Current & 1.19 Ampere \\
\hline
\end{tabular}

TABLE III. SPECIFICATIONS OF ARDUINO UNO R 3 DATALOGGER

\begin{tabular}{|c|c|}
\hline Parameters & Description \\
\hline Microcontroller & ATmega328 \\
\hline Effective Voltage & $5 \mathrm{~V}$ \\
\hline Suggested Input Voltage & $7-12 \mathrm{~V}$ \\
\hline Voltage limit & $6-20 \mathrm{~V}$ \\
\hline Digital Input/output Pins & 14 (of which 6 provide PWM output) \\
\hline Analog Input Pins & 6 \\
\hline DC Current per Input/output & $40 \mathrm{~mA}$ \\
\hline DC Current for 3.3 V Pin & $50 \mathrm{~mA}$ \\
\hline Flash Memory & $32 \mathrm{~KB}$ (ATmega328) of which $0.5 \mathrm{~KB}$ \\
used by boot loader
\end{tabular}

The sensors were pasted at different points on the fabricated system to examine PV modules temperature, water inlet and outlet temperature from radiator, heat exchanger temperature and air temperature when existing from PV module. The unit was interfaced with computer to store data. The data from the digital logger was stored in a memory card. The data of memory card was extracted through a computer and were further analyzed. A digital anemometer, Model PROVA AVM05 was used, its specifications are given in Table IV. Solar radiations were measured with the help of a lux meter on horizontal as well as on tilted surface. The fabricated system was installed over the roof of Energy and Environment Engineering Department, Nawabshah. The system was placed at latitude angle facing true south with the help of compass as shown in Figure 1.

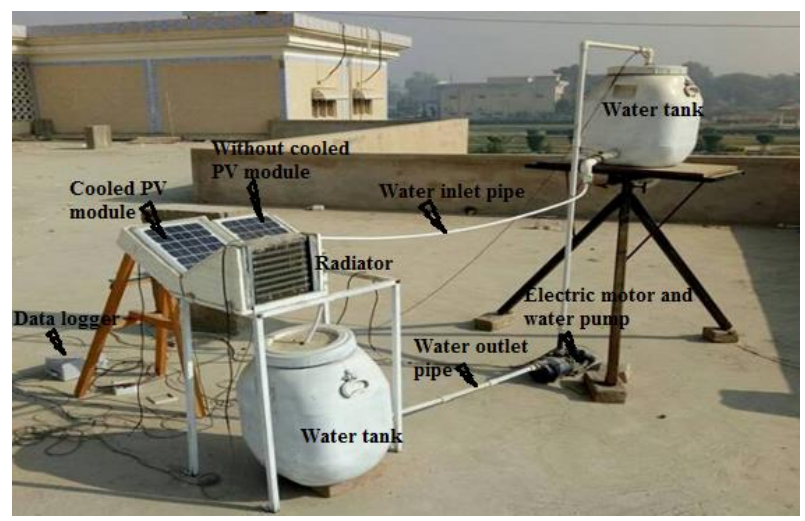

Fig. 1. Fabricated active cooling system.

\section{B. Procedure Adopted for Data Recording}

The installed unit was oriented at an inclination of $26.24^{\circ}$ to the horizontal facing true south. Two main parameters of system, namely PV module temperatures at different points and weather conditions were considered for this study. The temperatures at different points of systems, such as, cooled PV module temperature (Tcc), without cooled PV module temperature (Tcw), air temperature inlet PV module after radiator (Tci), air temperature outlet PV module (Tco), water temperature inlet of radiator (Tri), and water temperature outlet of radiator (Tro) were observed at two different flow rates of 1lit/min and 2lit/min. Weather conditions, such as solar radiations on horizontal surface and on tilted surface, wind speed and ambient temperature were recorded from 08:00 to 17:00 hours with one hour interval, thus allowing the knowing of the effect of atmospheric air cooling on the cooling of PV module and ultimately the performance improvements of PV modules. The experimental work was conducted for two weeks from Octomber $21^{\text {st }}$ until the November $4^{\text {th }}, 2016$. The weather conditions and temperatures at various points of installed PV system at the flow rate of 1 lit/min were observed for five days, and at the flow rate of 2 lit/min were also measured for another five days. The temperatures at different points of installed unit were recorded by the data logger and was extracted at the end of each day for analysis. The weather conditions were observed using lux meter and anemometer from 8:00 to 17:00 hours regularly. 
TABLE IV. SPECIFICATIONS OF DIGITAL ANEMOMETER

\begin{tabular}{|c|c|}
\hline Parameters & Description \\
\hline Type of Battery & $9 \mathrm{~V}$ \\
\hline Demonstration & $2 \times 4$ Digits Dual Display LCD \\
\hline Bearing & Sapphire jewel bearing \\
\hline Temperature Sensor & K-type thermocouple \\
\hline Temperature Range & $\begin{array}{c}\text { Meter: } 0 \sim 50(32 \sim 122) \\
\text { Vane: } 0 \sim 60(32 \sim 140)\end{array}$ \\
\hline Humidity Range & Less than $80 \% \mathrm{RH}$ \\
\hline Storage Temperature Range & $40 \sim 60(40 \sim 140)$ \\
\hline Power Consumption & Approx. 3mA \\
\hline Size & $\begin{array}{c}88 \times 168 \times 26.2 \mathrm{~mm} \\
\text { Vane: } 66 \times 132 \times 29.2 \mathrm{~mm}\end{array}$ \\
\hline Weight & $141 \mathrm{~g}$ \\
\hline
\end{tabular}

\section{RESULTS AND DISCUSSIONS}

The results obtained from the installed PV modules are illustrated with respect to two main parameters of system configurations, namely PV module temperatures at different points and weather conditions. The temperature of cooled and un-cooled PV module, air temperature at inlet and outlet of PV module, water temperature at inlet and outlet of radiator were observed at two different flow rates with 1 lit/min and 2 lit/min.

\section{A. Weather Conditions and Results with Flow Rate of 1 lit/min}

The results of average weather conditions and temperature of PV module at the flow rate of $1 \mathrm{lit} / \mathrm{min}$ are illustrated in Figures 2 and 3. The maximum average temperature of cooled (Tcc) and un-cooled (Tcw) PV module at flow rate of 1lit/min was recorded as $50.6^{\circ} \mathrm{C}$ and $54.5^{\circ} \mathrm{C}$ respectively. The average ambient temperature (Ta) was found $33^{\circ} \mathrm{C}$ with the average wind speed (WS) of $0.9 \mathrm{~m} / \mathrm{sec}$. The average solar radiations on horizontal surface $(\mathrm{GH})$ were found $604.4 \mathrm{~W} / \mathrm{m}^{2}$, and on the tilted surface (GT) $754.8 \mathrm{~W} / \mathrm{m}^{2}$. Likewise, the minimum average Tcc and Tcw PV module recorded was $48.34^{\circ} \mathrm{C}$ and $51.9^{\circ} \mathrm{C}$ respectively. The average ambient temperature (Ta) was $33.5{ }^{\circ} \mathrm{C}$, average WS $1.32 \mathrm{~m} / \mathrm{sec}$, and the average solar radiations on GH $588.2 \mathrm{~W} / \mathrm{m}^{2}$, and on GT was $731.8 \mathrm{~W} / \mathrm{m}^{2}$. Similarly, the overall average of mean temperature of cooled Tcc and Tcw PV module throughout these days was found as $49.2^{\circ} \mathrm{C}$ and $52.7^{\circ} \mathrm{C}$ respectively. The average Ta recorded was $32^{\circ} \mathrm{C}$, average WS $1.1 \mathrm{~m} / \mathrm{sec}$, and the average $\mathrm{GH}$ was $572.7 \mathrm{~W} / \mathrm{m}^{2}$, and GT was $705 \mathrm{~W} / \mathrm{m}^{2}$.

\section{B. Weather Conditions and Results with Flow Rate of 2 lit/min}

The results of average weather conditions and temperature of PV module at the flow rate of $2 \mathrm{lit} / \mathrm{min}$ are illustrated in Figures 4 and 5. The mean maximum average Tcc and Tcw PV module during data recording period with the flow rate of 2lit/min was recorded as $48.86^{\circ} \mathrm{C}$ and $52.3^{\circ} \mathrm{C}$ respectively. The average Ta was found $31.2^{\circ} \mathrm{C}$ with the average wind speed of $0.5 \mathrm{~m} / \mathrm{sec}$. The average solar radiation on horizontal surface was found $598.3 \mathrm{~W} / \mathrm{m}^{2}$, and on the tilted surface $754.3 \mathrm{~W} / \mathrm{m}^{2}$. Likewise, the mean minimum average temperature of Tcc and Tcw PV module recorded was $46.8^{\circ} \mathrm{C}$ and $50^{\circ} \mathrm{C}$ respectively. The average Ta was $31.4^{\circ} \mathrm{C}$, average WS $0.4 \mathrm{~m} / \mathrm{sec}$ and the average solar radiations on $\mathrm{GH}$ was $514.3 \mathrm{~W} / \mathrm{m}^{2}$, and on GT was $645 \mathrm{~W} / \mathrm{m}^{2}$. Similarly, the overall average of mean Tcc and
Tcw PV module throughout these data recording period with the flow rate of $2 \mathrm{lit} / \mathrm{min}$ was found as $48^{\circ} \mathrm{C}$ and $51.3^{\circ} \mathrm{C}$ respectively. The average Ta recorded was $32^{\circ} \mathrm{C}$, average WS $0.5 \mathrm{~m} / \mathrm{sec}$, and the average solar radiations on $\mathrm{GH}$ was $548 \mathrm{~W} / \mathrm{m}^{2}$, and on GT was $688.2 \mathrm{~W} / \mathrm{m}^{2}$.

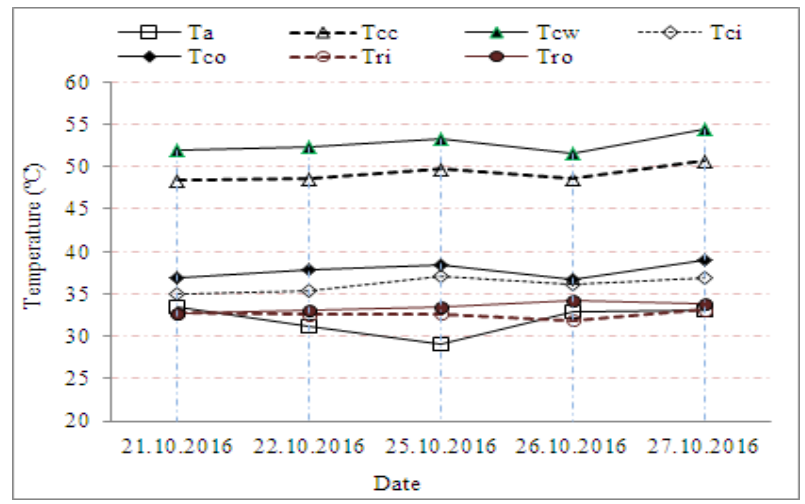

Fig. 2. Temperature at different points on PV system using flow rate of 1 lit/min.

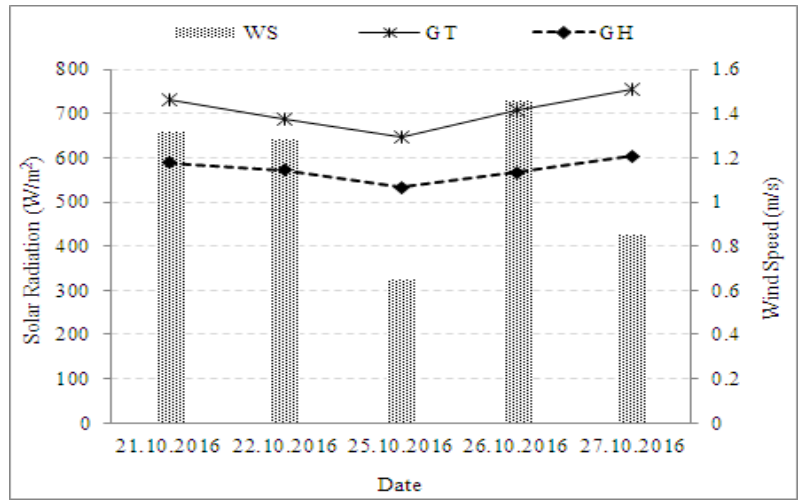

Fig. 3. Weather conditions of the site with the flow rate of 1 lit/min

\section{Comparision of Results with Different Flow Rate Conditions}

The average maximum, minimum and mean values of weather conditions and temperature of PV modules at the flow rate of 1lit/min and 2lit/min are presented in Figures 6 and 7. Both flow rates were maintained for five days period individually and then average results were framed for comparison purpose. The mean maximum average temperature of cooled (Tcc) and un-cooled (Tcw) PV module was recorded as $49.1^{\circ} \mathrm{C}$ and $52.7^{\circ} \mathrm{C}$ respectively at flow rate of $1 \mathrm{lit} / \mathrm{min}$. The average ambient temperature (Ta) was found $32^{\circ} \mathrm{C}$ with the average wind speed (WS) of $1.1 \mathrm{~m} / \mathrm{sec}$. The average solar radiations on horizontal surface $(\mathrm{GH})$ was found $572.7 \mathrm{~W} / \mathrm{m}^{2}$, and on the tilted surface (GT) $705 \mathrm{~W} / \mathrm{m}^{2}$. Likewise, the minimum average temperature of cooled (Tcc) and un-cooled (Tcw) PV module recorded was $48^{\circ} \mathrm{C}$ and $51.3^{\circ} \mathrm{C}$ respectively at flow rate of 2lit/min. The average ambient temperature (Ta) was $32^{\circ} \mathrm{C}$, average wind speed (WS) $0.5 \mathrm{~m} / \mathrm{sec}$, and the average solar radiations on horizontal surface $(\mathrm{GH}) 547.7 \mathrm{~W} / \mathrm{m}^{2}$, and on the tilted surface (GT) was $688.2 \mathrm{~W} / \mathrm{m}^{2}$. Similarly, the overall 
average of average temperature of cooled (Tcc) and un-cooled (Tcw) PV module throughout the data recording days at both flow rates of was found as $48.6^{\circ} \mathrm{C}$ and $52.01^{\circ} \mathrm{C}$ respectively. The average ambient temperature $(\mathrm{Ta})$ recorded was $32^{\circ} \mathrm{C}$, average wind speed (WS) $0.8 \mathrm{~m} / \mathrm{sec}$, and the average solar radiations on the horizontal surface $(\mathrm{GH})$ was $560.2 \mathrm{~W} / \mathrm{m}^{2}$, and on the tilted surface (GT) was $696.6 \mathrm{~W} / \mathrm{m}^{2}$.

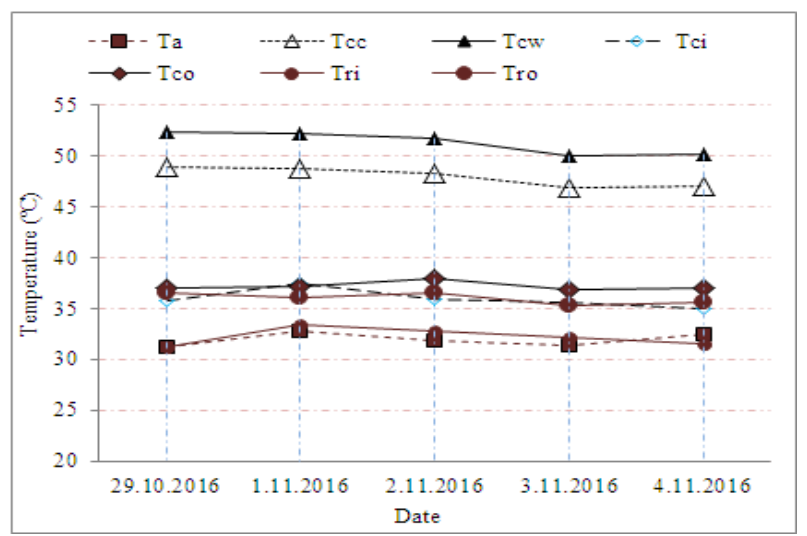

Fig. 4. Temperature at different points on PV system using flow rate of 2 lit/min.

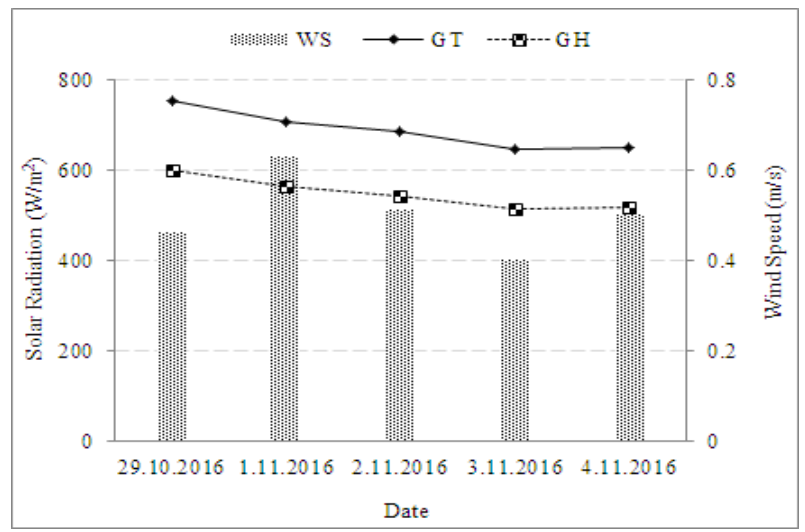

Fig. 5. Weather conditions of the site during flow rate of $2 \mathrm{lit} / \mathrm{min}$.

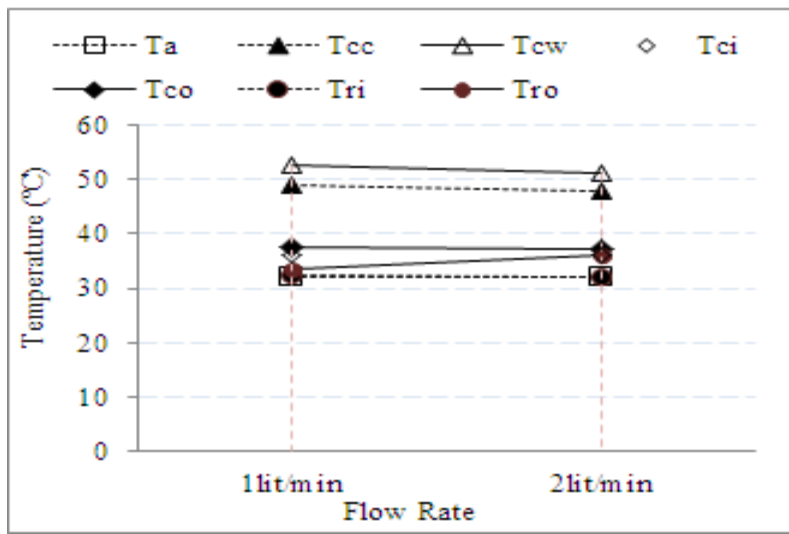

Fig. 6. Temperature at different points on PV system using variable flow rates

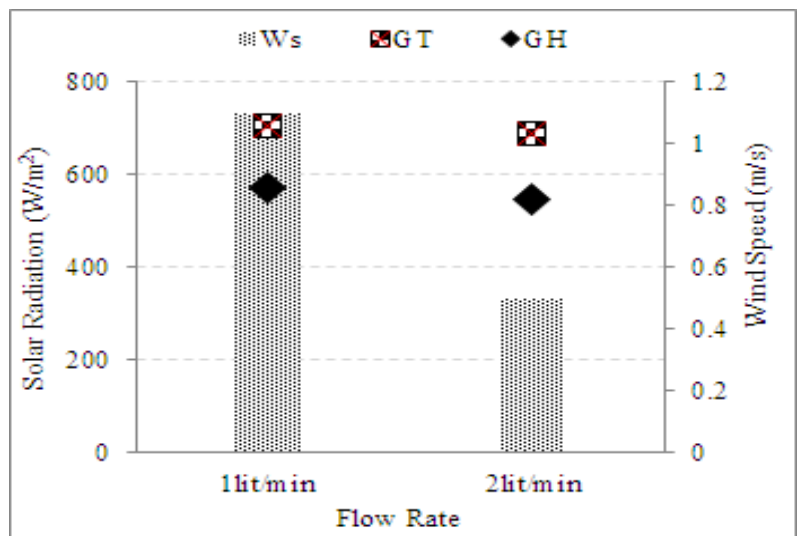

Fig. 7. Weather conditions during study period with variable flow rates.

\section{CONCLUSIONS}

Based on daily analysis, the maximum average temperature of cooled (Tcc) PV module recorded was $50.6^{\circ} \mathrm{C}$ and un-cooled (Tcw) was $54.5^{\circ} \mathrm{C}$, at the flow rate of 11 it $/ \mathrm{min}$. The heat extracted from the module was $7.2 \%$. Similarly, the minimum average temperature of cooled (Tcc) PV module recorded was $46.8^{\circ} \mathrm{C}$ and un-cooled (Tcw) $49.9^{\circ} \mathrm{C}$ at the flow rate of $2 \mathrm{lit} / \mathrm{min}$. It indicated the efficiency of $6.2 \%$ of heat extraction from the PV module. Based on overall average of all data collection days, the maximum average temperature of cooled module was $49.16^{\circ} \mathrm{C}$ and un-cooled module was $52.73^{\circ} \mathrm{C}$ at a flow rate of 1 lit/min, with indicates the heat extraction of $6.8 \%$. Since, the minimum average temperature of cooled PV module recorded was $47.9^{\circ} \mathrm{C}$ and un-cooled was $51.3^{\circ} \mathrm{C}$, which shows the heat extraction of $6.6 \%$. It was discovered from the analysis that the flow rate of $1 \mathrm{lit} / \mathrm{min}$ is more feasible for heat extraction as compared to the flow rate of $2 \mathrm{lit} / \mathrm{min}$. As far as weather conditions are concerned, the wind speed was found to be more helpful for heat extraction from the modules compared to other climatic parameters. In general, it is revealed that cooled monocrystalline PV module perform better with $6.7 \%$ more efficiency than un-cooled PV module. The present study was conducted by setting the PV module structure at the slope of $26^{\circ}$ with respect to horizontal surface, and the heat exchanger at $90^{\circ}$. Further study can be undertaken by changing the slope of the PV module structure and heat exchanger. The measurements were taken persistently for two weeks from 8:00 am to 5:00 pm with an interval of 1 hour during the months October and November. It is recommended that the measurements may be taken during summer months, so as to know the effect of atmospheric air cooling on the cooling of PV module during the hottest season of the year. The aluminum air cooled (radiator) heat exchanger is used in order to dissipate the heat of the air in to the water present in the tubes of heat exchanger. It is suggested that different types of heat exchangers may be tested for cooling of PV modules.

\section{ACKNOWLEDGMENT}

The authors acknowledge the financial support provided by the authorities of Quaid-e Awam University of Engineering, Science and Technology Nawabshah for the fabrication and analysis of the PV module cooling system. 


\section{REFERENCES}

[1] S. Rao, B. B. Parulekar, Energy Technology - Non Conventional, Renewable and Conventional, Third Revised and Updated Edition, Khanna Publishers, 2007

[2] A. Q. Jakhrani, A. K. Othman, A. R. H. Rigit, S. R. Samo, S. A. Kamboh, "A novel analytical model for optimal sizing of standalone photovoltaic systems", Energy, Vol. 46, No. 1, pp. 675-682, 2012

[3] S. A. Kalogirou, Solar energy engineering, Processes and systems Academic Press, 2013

[4] B. Mondoc, F. Pop, "Factors Influencing the Performance of a Photovoltaic Power Plant", 3rd International Conference on Modern Power System, Romania, May 18-21, 2010

[5] E. Gordo, N. Khalaf, T. Strangeowl, R. Dolino, N. Bennett, Factors Affecting Solar Power Production Efficiency, Supercomputing Challenge, Miyamura High School, 2015

[6] IEC 61724, Photovoltaic system performance monitoring-guidelines for measurement, data exchange and analysis, International Electrotechnical Commission, 1998

[7] C. U. Ike, "The effect of temperature on the performance of a photovoltaic solar system in Eastern Nigeria", Research Inventy: International Journal Of Engineering And Science, Vol. 3, No. 12, pp. $10-14,2013$

[8] E. Cuce, T. Bali, S. A. Sekucoglu, "Effects of passive cooling on performance of silicon photovoltaic cells", International Journal of LowCarbon Technologies, Vol. 6, No. 4, pp. 299-308, 2011

[9] R. Mazon-Hernasndez, J. R. García-Cascales, F. Vera-García, A. S. Kaiser, B. Zamora, "Improving the electrical parameters of a photovoltaic panel by means of an induced or forced air stream", International Journal of Photoenergy, Article ID 830968, 2013
[10] A. Hassan, Phase Change Materials for Thermal Regulation of Building Integrated Photovoltaics, PhD Thesis, Dublin Institute of Technology, 2010

[11] L. Micheli, E. F. Fernandez, F. Almonacid, T. K. Mallick, G. P. Smestad, "Performance, limits and economic perspectives for passive cooling of High Concentrator Photovoltaics", Solar Energy Materials and Solar Cells, Vol. 153, pp. 164-178, 2016

[12] C. G. Popovici, S. V. Hudisteanu, T. D. Mateescu, N. C. Chereches, "Efficiency Improvement of Photovoltaic Panels by Using Air Cooled Heat Sinks", Energy Procedia, Vol. 85, pp. 425-432, 2016

[13] M. S. Chandrasekar, S. Suresh, T. Senthilkumar, M. G. Karthikeyan "Passive cooling of standalone flat PV module with cotton wick structures", Energy Conversion and Management, Vol. 71, pp. 43-50, 2013

[14] H. G. Teo, P. S. Lee, M. Hawlader, "An active cooling system for photovoltaic modules" Applied Energy, Vol. 90, No. 1, pp. 309-315, 2012

[15] R. Hosseini, H. Naghmeh, H. Khorasanizadeh, "An experimental study of combining a photovoltaic system with a heating system", World Renewable Energy Congress, Linkoping, Sweden, May 8-13, 2011

[16] B. Du, E. Hu, M. Kolhe, "Performance analysis of water cooled concentrated photovoltaic (CPV) system", Renewable and Sustainable Energy Reviews, Vol. 16, No. 9, pp. 6732-6736, 2012

[17] H. Bahaidarah, A. Subhan, P. Gandhidasan, S. Rehman, "Performance evaluation of a PV (Photovoltaic) module by back surface water cooling for hot climatic conditions" Energy, Vol. 59, pp. 445-453, 2013

[18] K. A. Moharram, M. S. Abd-Elhady, H. A. Kandil, H. El-Sherif, "Enhancing the performance of photovoltaic panels by water cooling", Ain Shams Engineering Journal, Vol. 4, No. 4, pp. 869-877, 2013 